University of Nebraska - Lincoln

DigitalCommons@University of Nebraska - Lincoln

USDA Wildlife Services - Staff Publications

U.S. Department of Agriculture: Animal and Plant Health Inspection Service

January 2003

Determination of 4,4'-Dinitrocarbanilide (DNC), a Component of

Nicarbazin, in Canada Goose (Branta canadensis) Eggshells Using High-Performance Liquid Chromatography

\author{
Randal S. Stahl \\ USDA-APHIS-Wildlife Services, randal.s.stahl@aphis.usda.gov \\ Kurt C. VerCauteren \\ USDA-APHIS-Wildlife Services, kurt.c.vercauteren@usda.gov \\ Teresa L. Buettgenbach \\ USDA-APHIS-Wildlife Services \\ John J. Johnston \\ USDA-APHIS-Wildlife Services
}

Follow this and additional works at: https://digitalcommons.unl.edu/icwdm_usdanwrc

Part of the Environmental Sciences Commons

Stahl, Randal S.; VerCauteren, Kurt C.; Buettgenbach, Teresa L.; and Johnston, John J., "Determination of 4,4'-Dinitrocarbanilide (DNC), a Component of Nicarbazin, in Canada Goose (Branta canadensis) Eggshells Using High-Performance Liquid Chromatography" (2003). USDA Wildlife Services - Staff Publications. 271.

https://digitalcommons.unl.edu/icwdm_usdanwrc/271

This Article is brought to you for free and open access by the U.S. Department of Agriculture: Animal and Plant Health Inspection Service at DigitalCommons@University of Nebraska - Lincoln. It has been accepted for inclusion in USDA Wildlife Services - Staff Publications by an authorized administrator of DigitalCommons@University of Nebraska - Lincoln. 


\title{
Determination of 4,4'-Dinitrocarbanilide (DNC), a Component of Nicarbazin, in Canada Goose (Branta canadensis) Eggshells Using High-Performance Liquid Chromatography
}

\author{
Randal S. Stahl,* Kurt VerCauteren, Teresa L. Buettgenbach, and \\ JOHN J. JOHNSTON
}

USDA/APHIS/WS National Wildlife Research Center, 4101 LaPorte Avenue,

Fort Collins, Colorado 80521

\begin{abstract}
A method was developed using high-performance liquid chromatography to assay 4,4'-dinitrocarbanilide (DNC), the active ingredient in Nicarbazin, in eggshells collected from Canada geese fed a formulated feed fortified with Nicarbazin at doses of $0,125,250$, and $500 \mu \mathrm{g} / \mathrm{g}$. The method was developed using chicken eggshells fortified with DNC. The method was used to quantify DNC in both the shell-associated membranes and the calcified shell extracellular matrix. These values were compared to those obtained for a composite sample consisting of both the membranes and the calcified shell extracellular matrix. The validated method was used to quantify DNC in eggshells from geese fed fortified feed to ascertain the effect of Nicarbazin feed concentration on shell DNC concentration. DNC levels in the eggshells were highly correlated with feed dose.
\end{abstract}

KEYWORDS: 4,4'-Dinitrocarbanilide; DNC; Nicarbazin; Canada goose; eggshell; HPLC

\section{INTRODUCTION}

The need to develop tools to aid in the population control of rapidly increasing nonmigratory Canada goose (Branta canadensis) populations has become increasingly important in the face of concerns raised by property owners affected by these populations. Given the proximity of many of these populations to urban centers, the methods chosen must be socially acceptable. Nicarbazin is presently under investigation as a means of preventing the development of the embryo in eggs laid by geese by the U.S. Department of Agriculture/Animal Plant Health Inspection Service/Wildlife Services/National Wildlife Research Center (NWRC) for management of nonmigratory Canada goose populations.

Nicarbazin is an equal molar complex of $4,4^{\prime}$-dinitrocarbanilide (DNC; Figure 1) and 4,6-dimethyl-2-pyrimidinol (HDP; Figure 1). Nicarbazin is widely used in the poultry industry as a coccidiostat. DNC has a longer residence time than HDP in poultry. HDP is thought to aid in the uptake of the DNC and is rapidly excreted (1). Nicarbazin has been observed to affect egg viability when fed to layer hens (2) and appears to interfere with the formation of the yolk membrane, allowing the yolk and albumin to mix, preventing chick development. Nicarbazin reduces the hatchability in the eggs of geese in a similar manner (3). Numerous methodologies exist for assaying Nicarbazin, particularly DNC, in poultry egg contents and tissues (4-9). However, none have been developed for measuring Nicarbazin, as DNC, in eggshells exclusively.

* Author to whom correspondence should be addressed [telephone (970) 266-6062; fax (970) 266-6063; e-mail randal.s.stahl@aphis.usda.gov].
A<smiles>O=C(Nc1ccc([N+](=O)[O-])cc1)Nc1ccc([N+](=O)[O-])cc1</smiles>

B<smiles>Cc1cc(C)nc(O)n1</smiles>

Figure 1. Structures of 4,4'-dinitrocarbanilide (DNC) and 4,6-dimethyl2-pyrimidinol (HDP), the ingredients in Nicarbazin.

By monitoring the DNC levels in the hatched eggs it becomes possible to refine baiting strategies to allow for adequate population control without disrupting the nesting behavior of the geese. Collecting whole eggs from a nest for analysis can be disruptive and result in increased mating behavior. Also, the presence of nonviable eggs is not indicative of a treatment's success as environmental factors such as temperature and humidity play a large role in egg viability; a nonviable egg with DNC present may be nonviable due to some factor other than Nicarbazin dose. Establishing the dose effect independently of the environmental effects in a natural setting requires that the highest doses of Nicarbazin to be measured in the viable (successfully hatched) eggs be determined. Another complicating factor in determining dose response is that geese must be studied 
in natural environments as they are highly social birds and do not behave normally in isolated, controlled environments.

Earlier work at the NWRC sought to determine the optimal dose of Nicarbazin to induce nonviability in eggs in Canada geese (3). This work relied on assaying the egg contents to estimate the dose of Nicarbazin. At all levels of Nicarbazin in the feed (up to $500 \mu \mathrm{g} / \mathrm{g}$ ) some eggs were observed to hatch. The ability to determine an actual optimal dose was complicated by the reliance on analyzing egg contents. It was not possible to determine the dose received by eggs that appeared to be viable at collection (the egg contained an embryo) or eggs that hatched. To address these issues, we developed a method to assay the concentration of Nicarbazin in the eggshell by measuring the concentration of DNC in the shell.

The eggshell is a complex structure consisting of both calcified and uncalcified layers $(10-12)$. There are two noncalcified membranes associated with the shell in the early stages of embryo development, the outer shell membrane and the inner shell membrane (10-12). As the embryo develops, another membrane, the chorioallantoic membrane (CAM), is formed. This membrane fuses with the inner shell membrane and cannot be mechanically separated from it (12). In the chicken egg, the CAM is completely formed by the 14th day after fertilization, prior to organogenesis (12). The CAM becomes highly vascularized and is associated with gas exhange, waste excretion, and calcium mobilization for the developing embryo $(11,12)$.

The inner membrane/chorioallantoic membrane complex can be readily separated from the outer membrane/uncalcified extracellular matrix (ECM), and we refer to this complex as isolated membrane and make no distinction between these membrane layers. The calcified extracellular matrix often including the outer membrane is referred to as the shell. The extracellular calcified matrix and all of the noncalcified membrane matrices associated with the shell, regardless of the stage of development of the egg, are referred to as the eggshell.

Analysis of various organic contaminants, particularly chlorinated hydrocarbons, in the eggshell at different stages of egg development for various bird species has been used to predict exposure levels in the diet as well as in the general environment (13). Studies have often focused on pesticides in a single membrane structure at a given stage of development for the egg $(13-18)$. The levels of contaminants found in the isolated membranes tend to be correlated highly with the concentrations of pesticides found in the eggs themselves (13). These observations led us to believe that we could estimate Nicarbazin doses by measuring DNC in eggshells, so we developed a highperformance liquid chromatography (HPLC) method to quantify DNC in fortified chicken eggshells. The applicability of the method to goose eggshells was confirmed by extracting fortified goose eggshells. The method was then applied to the eggshells obtained from Canada geese fed Nicarbazin feed fortified at different levels of Nicarbazin with the objective of this field study to ascertain whether the DNC levels measured in the shells reflected exposure in the diet.

\section{MATERIALS AND METHODS}

Reagents. Solvents used include acetonitrile (ACN), Fisher HPLC grade, and $\mathrm{H}_{2} \mathrm{O}$, distilled. Chemicals used were Nicarbazin (Phibro Animal Health, San Diego CA), technical grade (certified 96.6\% pure).

High-Performance Liquid Chromatography. Standards and eggshell extracts were analyzed with an Agilent 1100 HPLC system with an MWD-UV detector. A $30 \mu \mathrm{L}$ sample was injected onto a Keystone ODS/H C-18 column, $5 \mu \mathrm{m}$ particle size, $4.6 \times 250 \mathrm{~mm}$, using a Keystone ODS/H $4.6 \times 15 \mathrm{~mm}$ guard column. The separation was performed using a gradient elution in a mobile phase of $40 \% \mathrm{ACN} /$
$60 \% \mathrm{H}_{2} \mathrm{O}$ increasing to $60 \% \mathrm{ACN} / 40 \% \mathrm{H}_{2} \mathrm{O}$ over 15 min. The final mobile phase composition was maintained for $10 \mathrm{~min}$. The flow rate was $1 \mathrm{~mL} / \mathrm{min}$ with a column temperature of $40^{\circ} \mathrm{C}$. DNC was measured at $\lambda=347 \mathrm{~nm}$. The column was allowed to re-equilibrate at the original conditions for 10 min between sample injections.

Sample Extraction and Analysis. Five matrices (DNC-fortified chicken eggshell, control chicken eggshell, DNC-fortified goose eggshell, control goose eggshell, and goose eggshell samples collected during a feeding study) were analyzed. In each case $5.0 \mathrm{~g}$ of eggshell was cut into strips, $<1.5 \mathrm{~cm}$ in width, to allow insertion in a test tube, and ground with a Brinkman Polytron in $7 \mathrm{~mL}$ of acetonitrile. The suspension was sonicated for 10 min using a Bransonic 20 ultrasonic bath and then shaken on an Eberbach horizontal shaker for $10 \mathrm{~min}$. The suspension was centrifuged for $2 \mathrm{~min}$ at $2500 \mathrm{~g}$. The supernatant was decanted. The extraction was repeated twice more, both times in $5 \mathrm{~mL}$ of acetonitrile. The suspension was sonicated only during the first extraction. The extraction volumes were combined and filtered through a Teflon filter disk ( $0.45 \mu \mathrm{m}$ pores). The volume was reduced under a gentle $\mathrm{N}_{2}$ stream at $60{ }^{\circ} \mathrm{C}$ using an N-Evap (Organomation, South Berlin, MA). The solution was brought to a final volume of 1.00 $\mathrm{mL}$ in acetonitrile. The solution was sonicated for $10 \mathrm{~min}$ using a Bransonic 20 ultrasonic bath, and an aliquot was filtered through a Teflon filter disk ( $0.45 \mu \mathrm{m}$ pores) into an LC vial and capped. Each goose eggshell was assayed twice. Values were averaged to calculate a shell concentration.

Method Development and Validation. The linear range of the method was established using standards prepared from stock solutions (1012 and $101 \mu \mathrm{g} / \mathrm{mL}$ ) at concentrations of $10.1,5.05,1.01,0.505$, 0.101 , and $0.020 \mu \mathrm{g} / \mathrm{mL}$ in acetonitrile. Standards were analyzed using the HPLC method described previously. Peak areas were regressed against concentration using SAS version 8.2. The residuals and the correlation coefficient were evaluated to determine linearity. The instrument limit of detection (ILOD) was calculated from the peak heights for the $0.02 \mu \mathrm{g} / \mathrm{mL}$ standard and a solvent (acetonitrile) blank, for which the ILOD was defined as a signal peak height 3 times the average baseline noise (peak to peak).

Extraction Validation. Chicken eggs were obtained from a local grocer. Organically raised, as well as traditionally raised, chickens were used as sources. Both white and brown eggshells were extracted to determine if shell pigmentation affected the analysis. Eggs were cracked open and the contents removed. The eggshells were gently rinsed in distilled $\mathrm{H}_{2} \mathrm{O}$. The eggshells were air-dried and then cut into strips. Eggshells were composited to provide $5 \mathrm{~g}$ samples. Samples were fortified with DNC in acetonitrile using stock solutions (9.92 and 99.2 $\mu \mathrm{g} / \mathrm{mL}$ ) to provide 0.0975 and $0.986 \mu \mathrm{g} / \mathrm{g}$ treatments. Samples were vortex mixed after fortification. Replicates of three samples at each fortification level were extracted on three separate days to provide both inter- and intraday recovery values. The method limit of detection (MLOD) was calculated from the peak height for the $0.0973 \mu \mathrm{g} / \mathrm{g}$ fortified samples and unfortified controls. The MLOD was defined to be the signal required to produce a peak height 3 times the baseline noise (peak to peak) in the unfortified controls. The limit of quantitation (LOQ) was calculated from the $0.0973 \mu \mathrm{g} / \mathrm{g}$ fortified samples and the unfortified controls. The LOQ was defined as the signal peak height required to produce a signal 10 times the baseline (peak to peak) in the unfortified controls.

Goose Feeding Field Study. Eighty-eight pairs of Canada geese were maintained in outdoor pens at a farm in Fillmore County, Minnesota. The pairs were randomly assigned to a Nicarbazin feeding regimen. There was one mated pair of geese per pen. The birds were fed $200 \mathrm{~g}$ of extruded feed containing $500,250,125$, or $0 \mu \mathrm{g} / \mathrm{g}$ Nicarbazin. These treatments were selected to target $6-8 \mu \mathrm{g} / \mathrm{mL}$ DNC in the blood plasma for a $4 \mathrm{~kg}$ goose consuming $100 \mathrm{~g}$ of the $500 \mu \mathrm{g} / \mathrm{g}$ treated feed. There were 22 pairs assigned to each treatment group. Feed was formulated by a local mill using a proprietary proven recipe developed by the owners of the geese to be fed during the laying season. The addition of Nicarbazin was the only modification to the recipe. Birds were fed the treated feed once a day. All breeding pairs were started with the treated feed on the same day. A pair was fed treated feed for approximately a week prior to the laying of the first egg in a clutch. The treated-feed regimen was provided until all of the eggs in 
a clutch were laid and the hen initiated incubation. For $80 \%$ of the birds the treatment duration ranged from 15 to 18 days. Once the treated feed had been consumed, a maintenance diet of untreated feed was provided. Eggs were labeled on the date they were laid.

Unhatched eggs and eggshells from eggs that had hatched were collected from 14 to 30 days after being laid in an attempt to collect eggs before they hatched, which occurred $\sim 28$ days after being laid. Eggs were stored at $-12{ }^{\circ} \mathrm{C}$ until analyzed. The shells were separated from the egg contents, rinsed with distilled $\mathrm{H}_{2} \mathrm{O}$, and stored frozen until analyzed. To verify that the method developed with chicken eggs was applicable, control goose eggshells were randomly selected and subsampled, fortified ( $n=5$ at each level) at $0,0.1$, and $1.0 \mu \mathrm{g} / \mathrm{g}$, and extracted using the described method. These were compared to the recovery data for fortified chicken eggshells using Student's $t$ test to test for significant differences in recovery. To establish the relationship between feed treatment and DNC levels in the eggshell, seven nonviable eggs were randomly selected at each of the treatment levels for analysis. Ten of these 28 eggs, three at each treatment level and one control, were subsampled to determine the distribution of DNC between the shell and the isolated membrane. Prior to analysis the shells were cut into strips and $\sim 5 \mathrm{~g}$ portions were weighed out. The shells were extracted as described above. The results from the eggshell assay were evaluated using analysis of variance (Excel, Microsoft) and Duncan's multiple-range test (19) to determine if significant differences in the mean eggshell DNC content were observed across feeding treatment levels. The concentrations determined for the shell and the isolated membranes were used to calculate the percent distribution of DNC in the shell.

\section{RESULTS AND DISCUSSION}

Method Validation. The standard curve for DNC was determined to be linear across the range of $0.02-10.1 \mu \mathrm{g} / \mathrm{mL}$ with an $r^{2}=0.9999$. The residuals for each standard data point were randomly distributed across the range indicating no confounding effect from dilution. Chicken eggshells were used as a surrogate matrix for goose eggs due to the ease with which they could be acquired. No effects of shell pigmentation were observed in the chromatography. No differences were observed in the chromatography when results from both organically and traditionally raised poultry were compared. Chromatograms from a control and from eggshells fortified at 0.0973 and $0.983 \mu \mathrm{g} / \mathrm{g}$ are presented in parts A, B, and C, respectively, of Figure 2. No coeluting peaks were observed in the control. The ILOD determined from the peak heights observed for the $0.18 \mu \mathrm{g} / \mathrm{mL}$ standards and the solvent was $0.0025 \mu \mathrm{g} / \mathrm{mL}$.

The method was validated by determining recoveries of DNC from chicken eggshell samples fortified at 0.0973 and 0.986 $\mu \mathrm{g} / \mathrm{g}$. Our laboratory QA procedures required mean recoveries to be $\pm 20 \%$ of recoveries observed for the same fortification level during method validation to be acceptable. No significant difference in the means (ANOVA) of the percent recoveries were observed at either level of fortification (Table 1). At the $0.0973 \mu \mathrm{g} / \mathrm{g}$ level, $\alpha=0.05, \mathrm{DF}=2,9, F_{\text {calcd }}=1.394, F_{\text {crit }}=$ 3.587 , and $P\left(F_{\text {crit }} \leq F_{\text {calcd }}\right)=0.296$; and for the $0.986 \mu \mathrm{g} / \mathrm{g}$ level, $\alpha=0.05, \mathrm{DF}=2,10, F_{\text {calcd }}=2.966, F_{\text {crit }}=3.490, P\left(F_{\text {crit }}\right.$ $\left.\leq F_{\text {calcd }}\right)=0.075$. The MLOD calculated from all of the 0.0973 $\mu \mathrm{g} / \mathrm{g}$ fortified samples and the unfortified controls during validation was $0.0027 \mu \mathrm{g} / \mathrm{g}$, corresponding to an LOQ of 0.0090 $\mu \mathrm{g} / \mathrm{g}$.

Chromatograms for control goose eggshells and eggshells fortified at 0.0984 and $0.984 \mu \mathrm{g} / \mathrm{g}$ are presented in parts A, B, and $\mathrm{C}$, respectively, of Figure 3. No coeluting peaks were observed in the control. The recoveries for the fortified goose eggshell samples (Table 1) were $96.2 \pm 13.4$ and $95.3 \pm 10.9 \%$ for the 0.0984 and $0.984 \mu \mathrm{g} / \mathrm{g}$ fortified samples, respectively.
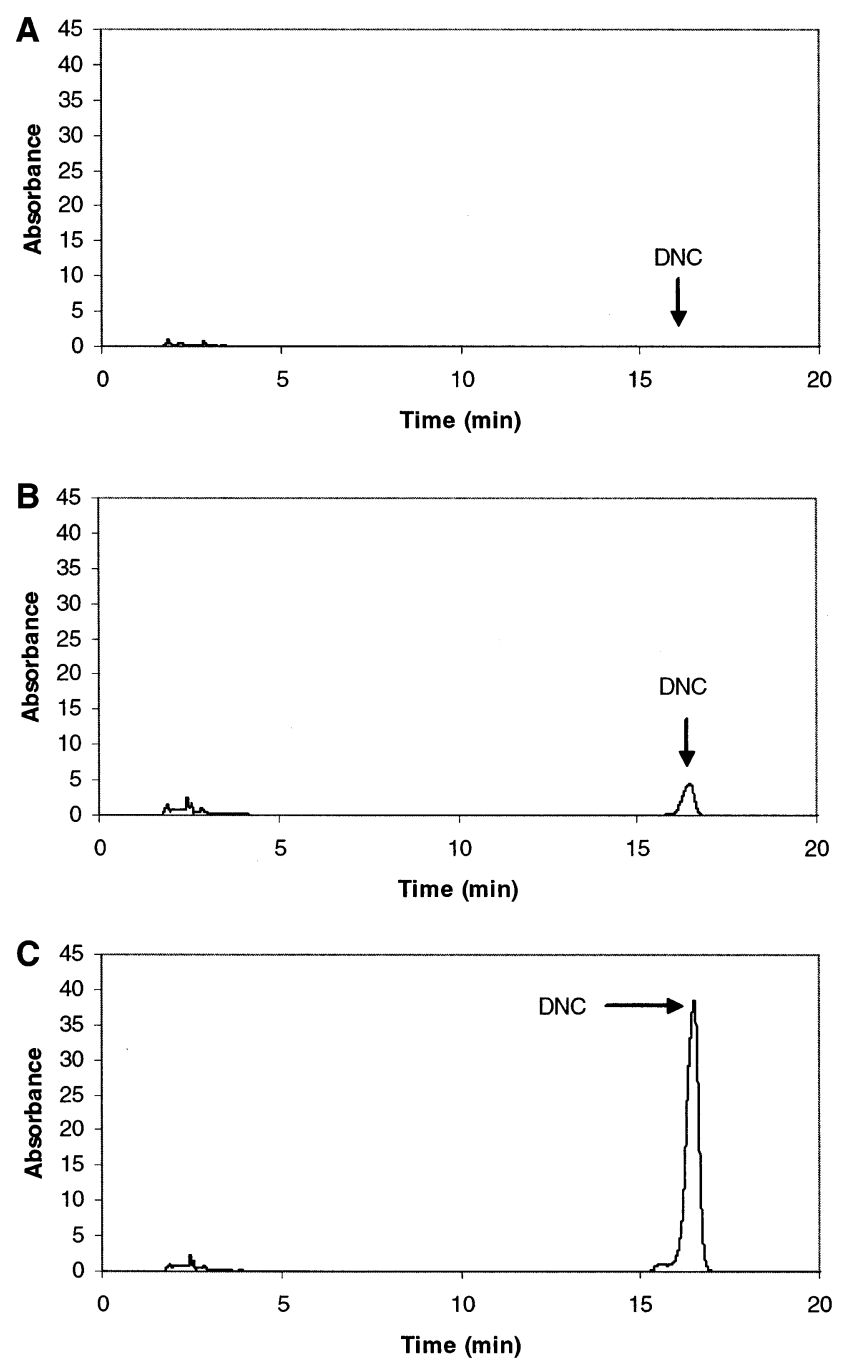

Figure 2. Chromatograms from DNC fortified chicken eggshell samples: control with no DNC (A); fortified at $0.0973 \mu \mathrm{g} / \mathrm{g}(\mathrm{B})$; fortified at 0.986 $\mu \mathrm{g} / \mathrm{g}(\mathrm{C})$.

Table 1. Percent Recovery Data for Fortified Chicken and Goose Eggshells

\begin{tabular}{|c|c|c|c|c|}
\hline collected on & $n$ & $\begin{array}{l}\text { mean fortification } \\
\text { level }(\mu \mathrm{g} / \mathrm{g})\end{array}$ & recovery (\%) & CV (\%) \\
\hline \multirow{4}{*}{ validation } & & Chicken Eggshells & & \\
\hline & 7 & controls & $<M L O D$ & $\mathrm{nc}^{\mathrm{a}}$ \\
\hline & 6 & 0.0973 & $88.4+10.0$ & 11.0 \\
\hline & 7 & 0.986 & $88.6+7.3$ & 8.3 \\
\hline \multirow[t]{3}{*}{ day 1} & 3 & controls & $<\mathrm{MLOD}$ & nc \\
\hline & 3 & 0.0984 & $86.1+17.8$ & 20.6 \\
\hline & 3 & 0.981 & $89.2+1.2$ & 1.4 \\
\hline \multirow[t]{3}{*}{ day 2} & 3 & controls & $<$ MLOD & nc \\
\hline & 3 & 0.0992 & $75.0+8.2$ & 11.0 \\
\hline & 3 & 0.983 & $79.0+1.9$ & 2.3 \\
\hline \multirow[t]{3}{*}{ day 3} & 3 & controls & $<\mathrm{MLOD}$ & nc \\
\hline & 3 & 0.0977 & $73.7+14.0$ & 19.0 \\
\hline & 3 & 0.991 & $88.6+7.3$ & 8.3 \\
\hline \multirow{4}{*}{ day 4} & & Goose Eggshells & & \\
\hline & 5 & controls & $<$ MLOD & nc \\
\hline & 5 & 0.0973 & $99.2+13.4$ & 13.9 \\
\hline & 5 & 0.986 & $95.3+10.9$ & 11.4 \\
\hline
\end{tabular}

a Not calculated.

There were no significant differences at the $\alpha=0.05$ level between the fortified goose eggshells and the fortified chicken eggshell data collected during method validation [Student's one- 

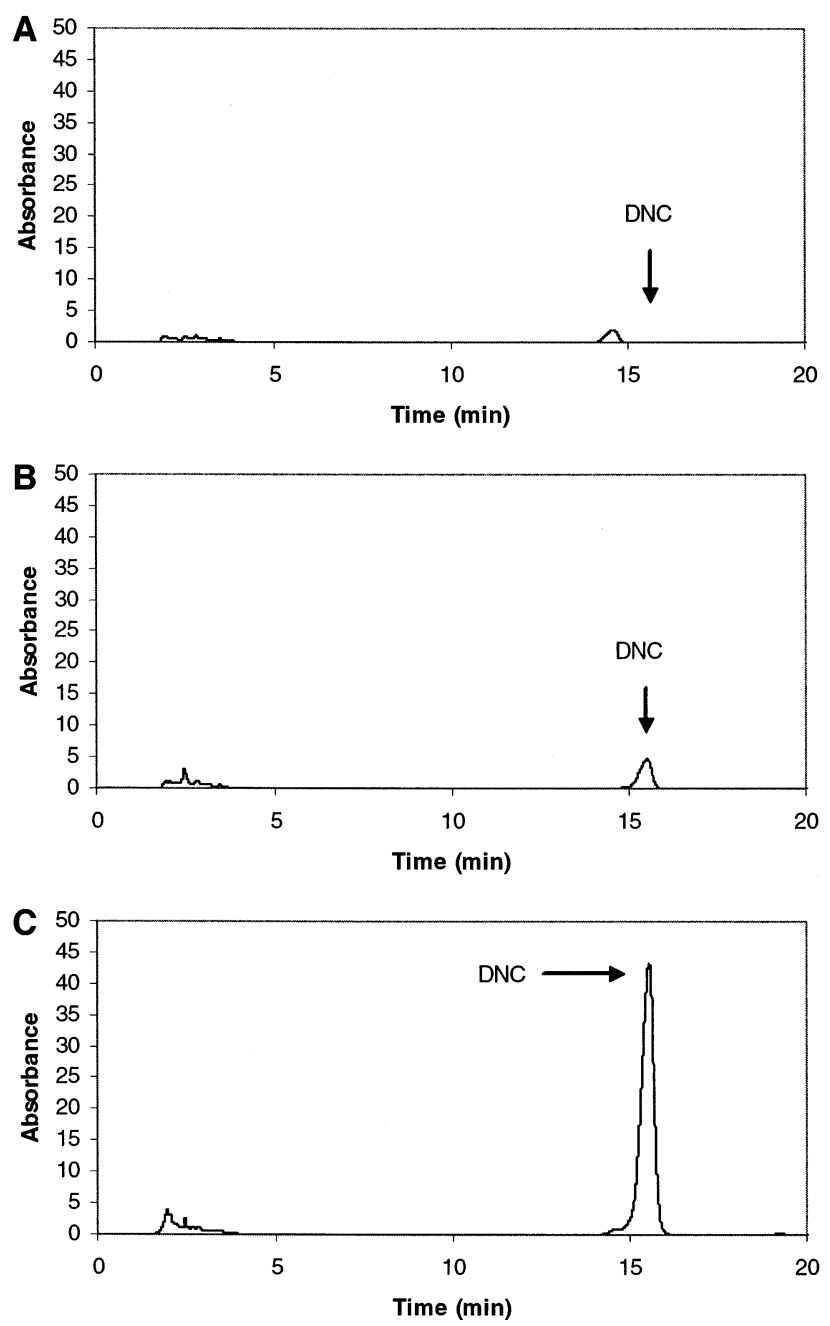

Figure 3. Chromatograms from fortified goose eggshells: control group sample (A); fortified at $0.0984 \mu \mathrm{g} / \mathrm{g}(\mathrm{B})$; sample fortified at $0.984 \mu \mathrm{g} / \mathrm{g}$ (C).

tailed $t$ test, $0.0984 \mu \mathrm{g} / \mathrm{g}$ goose eggshells versus $0.0973 \mathrm{mg} / \mathrm{g}$ chicken eggshells: $\mathrm{DF}=9, t_{\text {calcd }}=1.101, t_{\text {crit }}=1.833, P\left(t_{\text {crit }}\right.$ $\left.\leq t_{\text {calcd }}\right)=0.15$. $0.973 \mu \mathrm{g} / \mathrm{g}$ fortified goose eggshells versus the $0.986 \mu \mathrm{g} / \mathrm{g}$ fortified chicken eggshells: $\mathrm{DF}=10, t_{\text {calcd }}=$ $\left.1.28, t_{\text {crit }}=1.81, P\left(t_{\text {crit }} \leq t_{\text {calcd }}\right)=0.229\right]$. The MLOD calculated from all of the $0.0984 \mu \mathrm{g} / \mathrm{g}$ fortified samples and from all of the unfortified controls was $0.0026 \mu \mathrm{g} / \mathrm{g}$, corresponding to an LOQ of $0.0087 \mu \mathrm{g} / \mathrm{g}$.

Goose Feeding Field Study. Twenty-eight (seven replicates at each Nicarbazin feeding treatment level) eggs collected during the field study were randomly selected for determination of the DNC concentration in the eggshell. No coeluting compounds were detected in the control group eggshells (Figure 4A). The DNC levels in all of the control eggshells analyzed were below the MLOD. Peaks from eggshells in a feed treatment group were clearly resolved from baseline (Figure $\mathbf{4 B}$ is an example from the $500 \mu \mathrm{g} / \mathrm{g}$ Nicarbazin treatment group).

The means \pm 1 standard deviation $(s)$ for each egg analyzed in the three treatment feed groups (Table 2) were $0.094 \pm 0.071$ for the $125 \mu \mathrm{g} / \mathrm{g}$ feed treatment group, $0.189 \pm 0.130$ for the $250 \mu \mathrm{g} / \mathrm{g}$ feed treatment group, and $0.341 \pm 0.241$ for the 500 $\mu \mathrm{g} / \mathrm{g}$ feed treatment group. Using an ANOVA (Excel, Microsoft, $\alpha=0.05 ; \mathrm{DF}=2,38$; calculated $F=7.73$; critical $F=3.24$ ) the means were determined to be significantly different. Means were determined to be significantly different at $\alpha=0.05$ [Duncan's multiple-range test (19)]. The largest significant mean
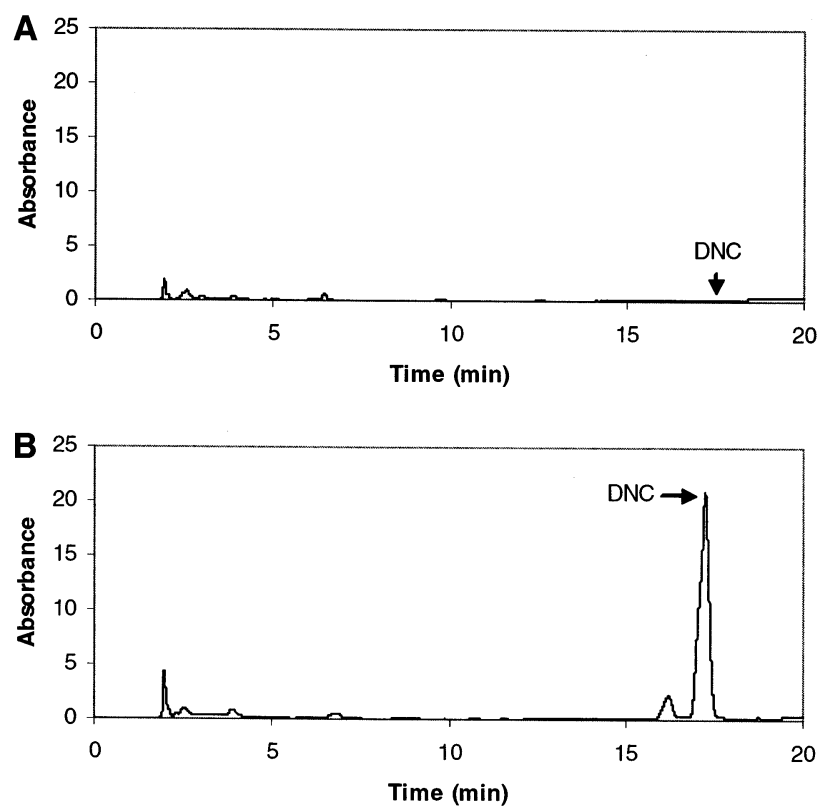

Figure 4. Chromatograms from goose eggshells: control group sample (A); sample from the $500 \mu \mathrm{g} / \mathrm{g}$ treatment group (B).

Table 2. Goose Eggshell DNC Analysis Results

\begin{tabular}{lcccc}
\hline egg & replicate & $125 \mu \mathrm{g} / \mathrm{g}$ & $250 \mu \mathrm{g} / \mathrm{g}$ & $500 \mu \mathrm{g} / \mathrm{g}$ \\
\hline 1 & 1 & $<\mathrm{LOQ}$ & 0.092 & 0.027 \\
& 2 & 0.009 & 0.022 & 0.032 \\
2 & 1 & 0.093 & 0.084 & 0.147 \\
& 2 & 0.089 & 0.020 & 0.094 \\
3 & 1 & 0.021 & 0.082 & 0.380 \\
& 2 & 0.030 & 0.072 & 0.598 \\
4 & 1 & 0.200 & 0.221 & 0.315 \\
& 2 & 0.260 & 0.198 & 0.296 \\
5 & 1 & 0.124 & 0.256 & 0.434 \\
& 2 & 0.130 & 0.215 & 0.463 \\
6 & 1 & 0.045 & 0.358 & 0.399 \\
& 2 & 0.070 & 0.371 & 0.169 \\
7 & 1 & 0.069 & 0.248 & 0.884 \\
& 2 & 0.086 & 0.405 & 0.536 \\
\multirow{2}{*}{ mean } & & 0.094 & 0.189 & 0.341 \\
$s$ & & 0.071 & 0.130 & 0.241 \\
\hline
\end{tabular}

difference required by the test was 0.083 , and the smallest difference observed between the means was 0.095. The observed trend in the means is consistent with the increase in magnitude in the treatments. These observations are consistent with the relationship between increases in DNC tissue concentrations and Nicarbazin dose reported in the literature for poultry $(20,21)$. The high variability between replicates for individual eggs is due in part to the irregular distribution of the membrane across the shell surface. The mass percentage (mass of membrane/ mass of eggshell) ranged from 9 to $16 \%$ for the isolated membranes (Table 3). In the early stages of development the CAM is not uniformly distributed and the eggs had different degrees of development, even within a treatment group. Many of the eggshells had highly vascularized membranes, reflecting the presence of the CAM and a high degree of development.

Comparison of the concentration of DNC in the shell and the isolated membrane showed that the concentration in the shell from the $125 \mathrm{mg} / \mathrm{kg}$ treatment group was less that the LOQ for all of the samples (Table 3). The average percent of the DNC in the isolated shell was $36.4 \pm 8.0 \%$ (mean $\pm 1 s$ ) of the DNC in the eggshell (shell and membrane) for shells sampled from the $250 \mathrm{mg} / \mathrm{kg}$ feed treatment and $38.6 \pm 4.5 \%$ for the 500 
Table 3. Concentrations of DNC for the Isolated Membranes and Eggshells by Feed Treatment Level

\begin{tabular}{|c|c|c|c|c|c|c|c|}
\hline \multirow[b]{2}{*}{ treament level $(\mu \mathrm{g} / \mathrm{g})$} & \multirow[b]{2}{*}{ replicate } & \multicolumn{3}{|c|}{ sample masses analyzed } & \multicolumn{3}{|c|}{ DNC concn } \\
\hline & & eggshell $(\mathrm{g})$ & membrane $(\mathrm{g})$ & total $(g)$ & membrane $(\mu \mathrm{g} / \mathrm{g})$ & egg shell $(\mu \mathrm{g} / \mathrm{g})$ & $\%$ DNC in shella \\
\hline control & 1 & 4.15 & 0.43 & 4.58 & $<\mathrm{MLOD}$ & $<\mathrm{MLOD}$ & \\
\hline \multirow[t]{3}{*}{125} & 1 & 4.42 & 0.50 & 4.92 & 0.062 & $<\mathrm{LOQ}$ & \\
\hline & 2 & 4.31 & 0.65 & 4.96 & 0.26 & $<\mathrm{LOQ}$ & \\
\hline & 3 & 4.24 & 0.47 & 4.71 & 0.43 & $<L O Q$ & \\
\hline \multirow[t]{3}{*}{250} & 1 & 4.64 & 0.63 & 5.27 & 2.7 & 0.15 & 29.0 \\
\hline & 2 & 4.27 & 0.60 & 4.87 & 0.68 & 0.078 & 44.9 \\
\hline & 3 & 4.44 & 0.39 & 4.83 & 1.86 & 0.089 & 35.3 \\
\hline \multirow[t]{3}{*}{500} & 1 & 4.07 & 0.83 & 4.90 & 1.99 & 0.23 & 36.2 \\
\hline & 2 & 4.23 & 0.50 & 4.73 & 3.48 & 0.23 & 35.9 \\
\hline & 3 & 4.45 & 0.44 & 4.89 & 1.94 & 0.15 & 43.9 \\
\hline
\end{tabular}

a $\%$ DNC in shell $=($ DNC concn in shell $\times$ mass of shell $) /($ DNC concn in membrane $\times$ mass of membrane + DNC concn in shell $\times$ mass of shell $) \times 100$.

$\mathrm{mg} / \mathrm{kg}$ feed treatment. The shells were significant contributors to the amount of DNC determined for the eggshell in the higher feed treatment groups. There was no relationship between the amount of DNC recovered from the membrane and the mass of the membrane extracted. The linear regression correlation coefficients for the amount of DNC extracted from the membrane versus the mass of the membrane are $0.033,0.152$, and 0.297 for the 125,250 , and $500 \mathrm{mg} / \mathrm{kg}$ treatment groups, respectively. The statistical analysis suffers from the constraint of a small sample size. The high variability in the subsamples mirrors that in the original shell samples. Our initial expectations were that the shell (eggshell isolated from the membranes) would not contribute significantly to the amount of DNC recovered from the eggshell. However, this proved to be untrue. This may result from an association of the DNC with the outer shell membrane, which was not separated from the ECM.

Historically, studies using eggshells to assess burden on the embryo have focused on one stage of development of the egg. This was not possible in this study as the objective was to assess the minimum dose necessary to prevent embryo development in the goose egg. The mechanism by which this occurs is not well understood. The stage at which an egg stopped developing may have been due to the Nicarbazin dose or due to an environmental factor such as thermal stress. To accurately assess the efficacy of Nicarbazin, the collection schedule sought to allow as many eggs to develop as possible. The time of collection and the degree of membrane development are known to affect recoveries of pesticides from egg membranes (13). We suggest this might also account for some of the variability observed.

There is debate in the literature regarding the passive versus active transport of organochlorine pesticides into and through the chorioallantoic membrane $(13-22)$.

Organochlorine pesticides have long residence times in tissues and are associated with the lipid fraction (13-18). Nicarbazin does not have long residence times in tissues. Nicarbazin is commonly fed to poultry at a dose of $125 \mathrm{mg} / \mathrm{kg}$ in feed. In radiolabeled isotope studies with chickens fed this dose for 3 days no activity could be measured in any tissues after 5 days following withdrawl of this dose (23). In poultry, DNC is observed to accumulate in the liver and kidneys preferentially to the muscle, skin, and fat (23). We associate the accumulation of the DNC in the eggshell with the waste accumulation functions accorded to the eggshell membranes as the embryo develops (11), with the understanding that there may be active transport of the DNC required for this to occur.

The decision to analyze the eggshell, instead of an isolated membrane, was based on the need for a method that would be applied to eggshells collected in the field (often the entire eggshell is not recovered) and a need to increase ease in handling of samples. The goose eggshells we analyzed had total masses between 12 and $20 \mathrm{~g}$. It was not uncommon to be able to recover only half of an eggshell from a hatched egg. This mass limitation poses serious constraints on a method, particularly one that requires only an intact-entire membrane. In all of the methods published to date in which an investigator analyzed pesticides in eggshell membranes, they analyzed the entire membrane. The inclusion of the shell greatly increased the sensitivity of the presented method.

Conclusion. The method developed for determining DNC in eggshells was successfully applied to the analysis of goose eggshells from geese fed different levels of Nicarbazin-treated feed. The levels of DNC observed in the eggshells (shell and membrane) were proportional to the levels fed to the geese in the feed. Including the shell in the extraction contributed significantly to the amount of DNC recovered in the extraction for the higher feed treatment groups. This method, based on analysis of the isolated membrane and the extracellular shell matrix combined, will be used to support future studies to establish the effective dose for Nicarbazin-treated feed fed to Canada geese as a means of preventing the development of the embryo in eggs by analyzing eggs that have hatched.

\section{LITERATURE CITED}

(1) Rogers, E. F.; Brown, R. D.; Brown, J. D.; Kazazis, D. M.; Leanz, W. J.; Nichols, J. R.; Ostlind, D. A.; Rodino, T. M Nicarbazin complex yields dinitrocarbanilic acid as ultrafine crystals with improved anticoccidial activity. Science 1983, 222, 630.

(2) Sherwood, D. H.; Milby, T. T.; Higgins, W. A. The effect of Nicarbazin on reproduction in White Rock breeder hens. Poult. Sci. 1956, 35, 1014.

(3) Johnston, J. J.; Britton, W. M.; McDonald, A.; Primus, T. M.; Goodall, M. J.; Furcolow, C. A.; Buttgenbach, T. L.; Kohler, D. J.; Miller, L. A.; Yoder, C. A.; Fagerstone, K. A. Quantification of plasma and egg 4,4'-dinitrocarbanilide (DNC) residues for the efficient development of a Nicarbazin based contraceptive. Pest Manag. Sci. 2002, 58, 197-202.

(4) Vertommen, M. H.; Van Der Laan, A.; Veenendall-Hesselman, H. M. High performance liquid chromatographic screening method for low levels of Nicarbazin in eggs with off-line cartridge sample clean-up. J. Chromatogr. 1989, 481, 452-457.

(5) Schenk, F. J.; Barker, S. A.; Long, A. R. Matrix solid-phase dispersion extraction and liquid chromatographic determination of Nicarbazin in chicken tissues. J. AOAC Int 1992, 75, 659662 .

(6) Tarbin, J. A.; Shearer, G. High-performance liquid chromatographic method for the determination of the dinitrocarbanilide component of Nicarbazin in eggs with on-line clean-up. $J$. Chromatogr. 1993, 613, 354-358. 
(7) Parks, O. W. Rapid procedure for the determination of Nicarbazin in tissues. J. Assoc. Off. Anal. Chem. 1988, 71, 778-780.

(8) Lewis, J. L.; Macey, T. D.; Garteiz, D. A. Determination of Nicarbazin in chicken tissues by liquid chromatography and confirmation by thermospray liquid chromatography/mass spectrometry. J. Assoc. Off. Anal. Chem. 1989, 72, 577-580.

(9) Draisci, R.; Lucentini, L.; Boria, P.; Lucarelli, C. Micro highperformance liquid chromatography for determination of Nicarbazin in chicken tissues, eggs, poultry feed, and litter. $J$. Chromatogr. A 1995, 697, 407-414.

(10) Romanoff, A. L.; Romanoff, A. J. The Avian Egg; Wiley: New York, 1949; p 143.

(11) Bellairs, R. Development of birds. In Biology and Comparative Physiology of Birds; Marshall, A. J., Ed.; Academic Press: New York, 1960; Vol. 1. pp 156-158.

(12) Diekert, J. W.; Diekert, M. C.; Creger, C. R. The avian shell membrane-a specialized extracellular matrix: Implications for differentiation of the chorioallantoic membrane. SAAS Bull.: Biochem. Biotechnol. 1992, 5, 30-37

(13) Cobb, G. P.; Norman, D. M.; Houlis, P. D.; Bargar, T. A. Using chorioallantoic membranes for nonlethal assessment of exposure and effect in oviparous wildlife. In Pesticides and Wildlife; Johnston, J. J., Ed.; ACS Symposium Series; American Chemical Society: Washington, DC, 2001; pp 275-293.

(14) Peakall, D. B.; Lew, T. S.; Springer, A. M.; Walker II, W.; Risebrough, R. W.; Monk, J. G.; Jarman, W. M.; Walton, B. J.; Reynolds, L. M.; Fyfe, R. W. Determination of DDE and PCB contents of Peregrin falcon eggs: A comparison of whole egg measurements and estimates derived from eggshell membranes. Arch. Environ. Contam. Toxicol. 1983, 12, 523-528.

(15) Peakall, D. B. DDE: Its presence in Peregrine eggs in 1948. Science 1974, 183, 673.
(16) Cobb, G. P.; Norman, D. M.; Kendall, R. J. Organochlorine contaminant assessment in Great Blue Herons using traditional and nonlethal monitoring techniques. Environ. Pollut. 1994, 83, 299-309.

(17) Cobb, G. P.; Norman, D.; Miller, M. W.; Brewer, L. W. Chlorinated contaminants in chorioallantoic membranes from Great Blue Heron eggs at Whidby Island Naval Air Station. Chemosphere 1995, 30, 151-164.

(18) Harper, F. D.; Waldrop, V. C.; Jeffers, R. D.; Duncan, C. D.; Cobb, G. P. Organochlorine and polychlorinated biphenyl contamination in Black Neck Stilt, Himantopus mexicanus, eggs from the savannah and Tybee National Wildlife Refuges. Chemosphere 1999, 39, 151-163.

(19) Steel, R. G. D.; Torrie, J. H. Principles and Procedures of Statistics; McGraw-Hill: New York, 1960; pp107-109.

(20) Cuckler, A. C.; Malanga, C. M.; Ott, W. H. The antiparasitic activity of Nicarbazin. Poult. Sci. 1958, 35, 98.

(21) Francois, A. C.; Pihet, A. J. Metabolism of Nicarbazin in chickens. Ann. Inst. Nat. Rech. Agron. Sec. D Ann. Zoolech. 1960, 9, 345.

(22) Pastor, D.; Ruiz, X.; Jover, L.; Albaiges, J. The use of chorioallantoic membranes as predictors of egg organochlorine burden. Environ. Toxicol. Chem. 1996, 15, 161-171.

(23) Food and Agriculture Organization. Residues in Some Veterinary Drugs in Animals and Foods; Geneva, Switzerland, 1999; 41/ 11, pp 83-93.

Received for review August 5, 2002. Revised manuscript received December 13, 2002. Accepted December 16, 2002.

JF025872U 